\section{REKONCEPTUALIZACIJA FREIREVOG NASLIJEĐA U KONTEKSTU SOCIJALNOG RADA}

Pregledni članak

Primljeno: siječanj, 2019.

Prihvaćeno: ožujak, 2020.

UDK 364.01: 37.013

DOI 10.3935/ljsr.v27i1.277

Jovana Škorić ${ }^{1}$

orcid.org/0000-0001-9028-2176

Sveučilište u Novom Sadu

Filozofski fakultet

Studijski program Socijalnog

rada

Marko Škorić ${ }^{2}$ orcid.org/0000-0002-4019-2807

Sveučilište u Novom Sadu

Filozofski fakultet

Odsjek za sociologiju

Ključne riječi:

Paulo Freire, kritička

pedagogija, kritički socijalni rad, osnaživanje, refleksivna praksa, socijalni radnici. 


\section{UVOD}

\section{Kratak osvrt na intelektualnu biografiju}

Paulo Freire (1921.-1997.) rođen je na sjeveroistoku Brazila u gradu Recife, u obitelji srednje klase. Uslijed Velike depresije njegova je obitelj bila prisiljena napustiti rodni grad i zbog sveprisutne gladi i siromaštva preseliti se u manji i jeftiniji grad. Rano je ostao bez oca, a zbog vrlo teških društvenih okolnosti u školi je u jednom trenutku zaostajao čak četiri razreda. Ova su iskustva utjecala na njegovu kasniju intelektualnu, ali i praktičnu brigu za siromašne i gladne, odnosno na odnos između društvene klase i znanja/obrazovanja. Studirao je pravo i filozofiju, naročito fenomenologiju, čiji je utjecaj primjetan u njegovim djelima (Gadotti, 1994.).

Nakon završetka Pravnog fakulteta predavao je portugalski jezik u brazilskim srednjim školama, a pored toga je radio kao odvjetnik i držao predavanja o raznim pravnim pitanjima i problemima (Collins, 1977.). Freireova misao o obrazovanju počela se uobličavati pedesetih godina, naročito kada je 1954. godine imenovan ravnateljem za obrazovanje i kulturu u SESI (Social Service for Industry). Nije se dugo zadržao na tom položaju, te nakon kritike na račun njegovog demokratskog, otvorenog i slobodnog stila vođenja administracije, podnosi ostavku (McLaren, 1996.). Šezdesetih je godina bio uključen i u popularni obrazovni pokret koji se bavio opismenjavanjem siromašnih, a do 1964. godine bio je profesor povijesti i filozofije obrazovanja na Sveučilištu Recife. Tada se u Brazilu događa državni udar, a Freire biva zatvoren zbog optužbi da je revolucionar. Po izlasku iz zatvora, proveo je četiri godine u Čileu i godinu dana u Sjedinjenim Državama. Tijekom 1970-ih godina preselio se u Ženevu, gdje je radio za Svjetski savez crkava i gdje osniva Institut za kulturne akcije, koji je pružao obrazovne usluge, osobito državama trećeg svijeta. U Brazil se vraća 1980. godine, a devet godina kasnije postaje tajnik za obrazovanje u Sao Paulu, gdje je tijekom mandata uložio velike napore kako bi svoje glavne ideje proveo u djelo (McLaren, 1996.).

Freire je danas poznat kao jedan od najutjecajnijih filozofa obrazovanja, čija je teorija o obrazovanju kao praksi slobode kao svoj sukus isticala da se ljudski potencijali mogu ostvariti samo preko svjesnog i namjeravanog oblikovanja povijesti i kulture, unatoč tomu što ljudi istovremeno bivaju oblikovani tom istom poviješću i kulturom (Collins, 1977.). Slobodna akcija sastoji se od povijesnosti i refleksivne akcije, odnosno praksisa, a ti kapaciteti, odnosno njihov razvoj, trebaju biti osnovni zadatak humanizirajućeg, odnosno oslobađajućeg obrazovanja (Freire, 1973.).

Dva najpoznatija Freireova djela su Pedagogija obespravljenih (1970.) i Pedagogija slobode (1996.) (u originalu Pedagogija autonomije). Prema službenim podacima 
Google Scholar, prva Freireova knjiga predstavlja jednu od najcitiranijih i najutjecajnijih knjiga u društvenim znanostima - prodana je u preko 800000 primjeraka i citirana je preko 100000 puta. Između objavljivanja ovih knjiga, Freire se kao teoretičar mijenjao, tako da među njima postoje stanovite razlike. Najvažnija se razlika ogleda u tomu što prva knjiga ukazuje na revolucionarno društvo, a druga brani demokratsko, dok u obje klasa predstavlja glavnog pokretača povijesti. Također, u prvoj knjizi glavni dijalektički parovi su: (1) tlačitelj i potlačeni i (2) bankarska i oslobađajuća pedagogija, dok u drugoj postoje suprotstavljenosti između (1) humanizacije i dehumanizacije, (2) pozitivizma i dijalektike i (3) hijerarhije i dijaloga.

Pored ovih, objavio je još dvadesetak knjiga koje su prevedene na desetine jezika, a preko dvadeset sveučilišta diljem svijeta dodijelilo mu je počasni doktorat (lat. honoris causa). Posljednjih se godina života bavio i ekopedagogijom, koja nastaje i kasnije se razvija pod njegovim utjecajem, kao logički nastavak teorije i prakse kritičke pedagogije (npr. Freire, 2004.). Smatrao je da ekologija mora biti prisutna u svakoj praksi, te je govorio o vezi između obrazovanja i održivog razvoja. Drugačije rečeno, zadatak ekopedagogije je razviti osjećaj i svijest o kolektivnim potencijalima čovječanstva, kao i socijalnu pravdu, a to preusmjerenje obrazovanja treba početi od načela održivosti, što podrazumijeva reviziju nastavnih planova i programa, obrazovnih sustava, uloge škole i edukatora itd. Ona je orijentirana k budućnosti i predstavlja jednu vrstu ekološke i političke vizije koja se suprotstavlja, prije svega neoliberalizmu i imperijalizmu, a istovremeno promovira kritičku ekopismenost (razumijevanje prirodnih sustava koji omogućavaju život) (Kahn, 2010.). U tom smislu, ekopedagogija treba pomoći razvijanju oblika znanja koji su ukorijenjeni u održivosti (održavanje promjena, ali koje su u skladu s trenutnim i budućim ljudskim potrebama), planetarnosti, odnosno kozmopolitizmu i biofiliji, što je ideja Ericha Fromma (1964.), koju je popularizirao Edward Wilson (1984.), a koja pretpostavlja da ljudi imaju urođene težnje biti povezani s prirodom i ostatkom živoga svijeta (Gadotti i Torres, 2009.).

\section{Freire i kritička pedagogija}

Freire je svoj obrazovni i filozofski projekt promatrao kao misiju koja je bila inspirirana religioznošću i političkim ciljem oslobađanja ljudi. Želio je da potlačeni, a na koncu i tlačitelji, budu svjesni svojega stanja, kako bi uopće mogli poželjeti promijeniti ga. Međutim, bit nije bila samo u intelektualnom oslobođenju, nego i u egzistencijalnom, te je krajnji politički cilj ovakve filozofije obrazovanja promijeniti ne samo okolnosti u kojima ljudi žive, već promijeniti društvenu stvarnost bez opresije. Kada se takva stvarnost promijeni, proturječnost između edukatora i osobe koja se obrazuje nadilazi se dijaloškim odnosom, a pedagogija potlačenih, odnosno obespravljenih, 
pretvara se u oslobađajuću pedagogiju za sve ljude (Freire, 1970., 1976.). Ovo je bit takozvane kritičke pedagogije, s kojom se najčešće povezuje upravo Freire.

U pitanju je istovremeno i filozofija obrazovanja i društveni pokret koji se, kako i samo ime govori, prvenstveno razvio iz kritičke teorije društva, ali i srodnih tradicija filozofije obrazovanja (Gottesman, 2016.). Najopćenitije rečeno, kritička pedagogija podučavanje i učenje promatra kao političke procese, što znači da odbacuje stajalište o neutralnosti znanja i kao glavni cilj ima emancipaciju od potlačenosti koja se može postići razvijanjem kritičke svijesti, odnosno osvještavanjem, jer tek tada pojedinci preko kritike društvenih okolnosti i političke akcije mogu pokušati mijenjati opresivni sustav. Ove ideje nisu nove, jer su o konstruiranju znanja sa studentima pisali, na primjer, Dewey (1902.) i Vygotski (1978.), dok je početkom prošloga stoljeća društveni rekonstrukcionizam bio utemeljen na ideji da škole mogu i trebaju utjecati na društvenu promjenu, odnosno već se isticalo kako one mogu i trebaju biti djelatne sile promjene. Zato postoje određene sličnosti s pokretom progresivnog obrazovanja, konstruktivizmom i multikulturnim obrazovanjem (vidi npr. Hayes, 2006.; Piaget, 1972.).

Ipak, možda je lakše shvatiti protiv čega kritička pedagogija jest, nego za što se točno zalaže. Ona je, prije svega, protiv mainstream paradigme obrazovanja, odnosno kritizira njezine dvije glavne premise. Prva je ideja da su škole mehanizmi izjednačavanja ili niveliranja, odnosno neka vrsta institucija koje su meritokratske i koje nude jednake šanse svima. Kritička pedagogija ističe kako to nikad nije bio slučaj i da škole prije reproduciraju postojeće nejednakosti ili legitimiziraju ovu reprodukciju. Na ovome se mjestu i zagovornici kritičke pedagogije mogu razlikovati po pitanju toga slažu li se s liberalnom pozicijom, koja ishod nejednakosti u školama promatra kao iznimku koji je posljedica nesavršenstva školskog sustava, jer se škole mogu promatrati i tako kao da imaju za cilj reproducirati nejednake ishode, samim tim i nejednakosti (npr. Spring, 1989.). Zato se mogu razlikovati liberalnije i radikalnije verzije kritičke pedagogije (Cho, 2013.). Pored toga, moguće je biti zagovornikom kritičke pedagogije i baviti se samo učenjem, odnosno mikrorazinom, ili se usredotočiti na makrorazinu i šire odnose moći između obrazovanja i društva (vidi npr. Kanpol, 1999.).

Freireova kritička pedagogija suprotstavlja se i tzv. instrumentalnom mišljenju. Mainstream paradigma obrazovanja školovanje vidi kao sredstvo za ostvarenje cilja i za individue i za društvo, dok kritička pedagogija kritizira ovu instrumentalnu racionalnost i reifikaciju, jer dovode do dehumanizacije i opresije. Kritizirao je brazilsku vladu jer je pismenost tretirala kao tragičnu socijalnu bolest bez lijeka te je, analizirajući brazilski obrazovni sustav, redefinirao nepismenost od društvene bolesti do konkretnog izraza nepravde društvene stvarnosti (Freire, 1970.). Zato njegova kritička pedagogija pokušava transformirati škole u smjeru humanizacije i društvene promjene i promatra ih kao društvene institucije koje trebaju pokušati mijenjati, a ne kao 
institucije koje za cilj trebaju imati postojeći društveni sustav (Freire, 1970., 1972., 1976.). Lako se vidi kolik je u kritičkoj pedagogiji značaj politike koja se usredotočuje na moć i njezine odnose s obrazovanjem, jer Freire škole i obrazovanje nije vidio kao mehanizme društvene kontrole i reprodukcije, nego je smatrao kako mogu biti oslobađajući tako što će razvijati kritičku percepciju stvarnosti među učenicima, što može dovesti do osviještenja. Ove je procese nazvao metodologijom osvještavanja, a edukatori diljem svijeta uzeli su ove elemente teorije, osobito ideju o kontrastu između tradicionalnog školovanja ("bankarskog obrazovanja") i obrazovanja kao prakse slobode (obrazovanje koje postavlja i analizira probleme). Iz ovoga slijedi kako se Freireova kritička humanizirajuća pedagogija mogla primijeniti i na djecu i na odrasle.

Zbog svega navedenog, nekada nije jednostavno reći gdje su granice Freireove kritičke pedagogije, odnosno u kojoj se mjeri ista prelijeva i u druga srodna područja poput socijalnog rada, sociologije, antropologije itd. Pored toga, misao Paula Freirea iznimno je kompleksna i raznovrsna, te je nemoguće ponuditi kratak i sveobuhvatan pregled. Iz toga razloga, naglasak će u daljnjem tekstu biti na njegovim općim idejama koje se izravno mogu dovesti u vezu sa socijalnim radom, a iste ćemo grupirati u tri ključna područja: (1) kritički socijalni rad, osnaživanje i preispitivanje pozicije socijalnog rada u društvu, (2) ideje koje se mogu koristiti za rekonceptualizaciju odnosa socijalnog radnika i korisnika usluga i (3) ideje koje idu u pravcu promišljanja o rastu i razvoju socijalnih radnika kao profesionalaca.

\section{KRITIČKI SOCIJALNI RAD, OSNAŽIVANJE I PREISPITIVANJE POZICIJE SOCIJALNOG RADA U DRUŠTVU}

Freireovu kritičku pedagogiju možemo povezati s idejama frankfurtske škole. Naime, poput frankfurtske škole, i Freireova kritička pedagogija kreće se u pravcu socijalnih reformi (vidi i Freire, 1970.; Horkheimer, 1982.). Ovu školu kritičke teorije činili su disidentski marksisti, kritičari kako kapitalizma, tako i sovjetskog socijalizma, koji su nastojali unaprijediti Marxovu misao putem kritike suvremenog društva, koristeći uvide antipozitivističke sociologije, psihoanalize, egzistencijalističke filozofije i slično. Dakle, osnovne su namjere ove perspektive bile "pregledanje" marksizma i analiziranje površnih slojeva kulture. Oni praktično kritiziraju postojeću kulturu i ideologiju, a smatraju da su problemi koji proizlaze iz njih rasna nejednakost, nedostatak jednakih mogućnosti za sve, rodna nejednakost itd. Naime, kao što smo vidjeli, kritička teorija ima svoje korijene u Europi, a razvijali su je teoretičari poput Horkhaimera, Adornoa, Habermasa i drugih (Best, Bonefeld, i O'Kane, 2018.; Gordon, Hammer i 
Honneth, 2019.). Teoretičari frankfurtske škole ne zagovaraju objektivnost, smatrajući je načinom promicanja i/ili prikrivanja odnosa društvene dominacije. Umjesto toga, vlastitu će teoriju smatrati emancipatorskom, odnosno teorijom koja zagovara slobodu, jednakost i bratstvo u prosvjetiteljskoj tradiciji, što su vrijednosti koje ovi teoretičari smatraju nekompatibilnim s kasnim kapitalizmom, tehnološkom logikom, konzumerizmom i masovnom kulturom.

Imamo li pak na umu socijalni rad, kritička tradicija ima dugu i bogatu povijest u ovom području, dok Freire predstavlja autora čije su ideje nadahnule pojavu istog (npr. Addams, 1961.; Franklin, 1986.; Fook, 2002.; Ferguson, 2008.). Naime, na kritički socijalni rad snažno su utjecale i ideje marksizma, franfkurtske kritičke teorije i raniji pristupi radikalnog socijalnog rada. Ili drugim riječima, kritički socijalni rad razvio se zbog suprotstavljanja svim oblicima ugnjetavanja. Noviji teoretičari poput Fergusona, Whitea, Dominelli, Garrettea dalje su razvili ovu paradigmu uključivanjem interdisciplinarnih ideja iz suvremene političke filozofije, antropologije i drugih društvenih teorija. Ključna ideja kritičkog pristupa je usredotočenost na društvene strukture i na "neokrivljavanje pojedinačne žrtve" (vidi i Fook, 2002.). Odnosno, kako tvrde neki autori (npr. Dominelli, 2002.), ovaj pristup usredotočen je na strukturalne odnose moći i modele dominacije tražeći strukturne promjene i potičući pozitivne ideale. Ovdje je bitno naglasiti koncept moći, prije svega transformacijske moći. Dominelli, slično Freireu, upozorava da je potrebno uraditi jasnu distinkciju između moći kao dominacije i između moći kao potencijala za poduzimanje različitih akcija u pravcu zajedničkog cilja (Dominelli, 2002.).

Zašto je kritička perspektiva značajna za praksu socijalnog rada? Kritička perspektiva pomaže socijalnim radnicima izbjeći pretpostavku kako stvari moraju ostati takve kakve jesu, odnosno uzimati stvari "zdravo za gotovo" - upravo kako je i sam Freire tvrdio. Odnosno, ova perspektiva nudi kritike i alternative postojećem društvenom poretku. Imajući to u vidu, praktičari mogu analizirati i baviti se društvenim čimbenicima koji su u temeljima sadašnjih problema s kojima se suočavaju korisnici, ali i sami socijalni radnici. Općenito, ona uključuje interpretacije različitih problema (i akcija) koji su aktualni u trenutnom političkom i društvenom kontekstu, naglašavajući mogućnosti za društvenom transformacijom. Moglo bi se reći kako je uporišna točka kritičke teorije socijalnog rada mogućnost osiguravanja svim građanima prilike za zdrav i društveno koristan život ili, drugim riječima, da svi građani imaju mogućnost osigurati zadovoljenje svojih potreba uz poštovanje načela demokratičnosti (Payne, 2006.). Pored toga, kritički socijalni rad usredotočuje pozornost na subjektivnu konstrukciju socijalnog radnika, ali i na dekonstrukciju klijentove situacije kao važne determinante $u$ analizi određenog problema (Fook, 2002.). 
U kontekstu današnjeg socijalnog rada, često nam ideologije paternalizma koje prožimaju kulture birokratsko strukturiranih institucija socijalne zaštite predstavljaju barijeru k razvoju dijaloga (o kojemu će nešto kasnije biti više riječi) između socijalnog radnika i korisnika. Jedna od posljedica u praksi očituje se i u tome da socijalni radnik postaje agent socijalne kontrole za održavanje statusa quo i uravnoteženosti, odnosno socijalni radnici postaju "meki policajci" (vidi i Webb, 2006.). Naime, većina institucija socijalne zaštite je hijerarhijski organizirana, te često dolazi do sukoba između "profesionalne autonomije" i organizacijskih ograničenja. Za razliku od toga, Freire smatra da postoji alternativni odnos koji opisuje kao vodoravni. Ovaj odnos posvećen je ravnopravnosti, ukidanju privilegija i ne-elitističkim oblicima vodstva (Goroff, 1981.).

Freire smatra da je funkcioniranje društva konstantno onemogućeno nepravednošću, eksploatacijom, ugnjetavanjem, diskriminacijom i nasiljem nad potlačenima. Kako bi ljudi mogli nadići to stanje ugnjetavanosti i osjećaj osobne nesposobnosti, potrebna je pomoć i potpora zajednice (Freire, 1998.a). U tom smislu, Freireove misli i tvrdnje vrlo su dragocjene u pristupima socijalnog rada koji su utemeljeni na snazi, odnosno osnaživanju (Solomon, 1976.; Labonte, 1990.; Rose, 2000.; Hegar, 2012.). Moglo bi se reći kako jezgra akcija usmjerenih k osnaživanju uključuje podizanje svijesti kroz kolektivne i individualne akcije kako bi se izgradila moć koja bi omogućila da se isključene i potlačene društvene grupe mobiliziraju i traže svoja prava kroz borbe za prevlast i eventualnu transformaciju statusa quo (Freire, 1970.; Cornwall i Brock, 2005.; vidi i Bilinović i Škorić, 2015.). Sukladno tome, definicije osnaživanja posebice su usmjerene na stjecanje kontrole nad životom, na proširenje moći, pravo glasa, autonomiju osobe, promociju slobode u raznim kontekstima i sl. (Parsons, 1991.). Na temelju toga može se zaključiti kako je osnaživanje multidimenzionalan i društveni proces. Multidimenzionalan u smislu da se odvija u okviru psiholoških, socioloških, ekonomskih i drugih dimenzija, a rečeno je da se odvija i na različitim razinama kao što su pojedinci, skupine, organizacije i/ili zajednice. Ono je i društveni proces, jer se uvijek javlja u odnosu na druge ljude (Rappaport, 1984.).

Filozofija osnaživanja zapravo zastupa ideju perspektive moći i razvoja kapaciteta pojedinca (skupine ili zajednice) s ciljem poboljšanja njegova života (Payne, 2005.), što znači da se osnaživanje može razumjeti (samo) kroz proces promjene. U tom smislu, ono je "interaktivni proces kroz koji ljudi doživljavaju osobne i društvene promjene, omogućavajući im da poduzmu mjere kako bi ostvarili utjecaj na organizacije i institucije koje utječu na njihov život i zajednice u kojima žive" (McClelland, 1975.: 13). Kroz Freireov rad, osnaživanje se može sagledati na tri razine: (1) na osobnoj, gdje je u pitanju iskustvo pojedinca u postizanju sve veće kontrole i utjecaja nad svojim odlukama u svakodnevnom životu, (2) na razini (malih) skupina, gdje uključuje zajed- 
ničko iskustvo koje može potaknuti zajedničke akcije i (3) na razini zajednice, gdje se osnaživanje ostvaruje kroz korištenje raznih resursa i strategija za poboljšanje pristupa zajednici (vidi i Labonte, 1990.).

Freire (1970.) u svojemu radu naglašava da potlačeni ljudi nemaju osobne, moralne ili duhovne snage ili resurse, već su im životne šanse znatno okrnjene društvenom nejednakošću. Odnosno, društvena nejednakost, kako kaže Freire, predstavlja veliki društveni problem u mnogim zemljama svijeta. Ona ima jasne implikacije na društveni život, odnosno može utjecati na siromaštvo, isključivanje iz sustava obrazovanja (vidi i Bourdieu, 1988., 1993.), na izostanak i/ili manjkavost zdravstvenih i/ili socijalnih usluga (vidi i Dearing, 2017.), participaciju u društvu (vidi i Lancee i Werfhorst, 2012.) i mnoga druga područja. S druge strane, ne postoji konsenzus kada je u pitanju objašnjenje uzroka društvene nejednakosti. Primjerice, ako se socijalni radnik susretne s primjerom siromaštva, nezaposlenosti ili beskućništva, njegova početna reakcija mogla bi ići u smjeru traženja odgovora u samom korisniku. Odnosno, pitanjem čime je ta osoba prouzročila takav položaj u društvu? Nažalost, takav odgovor je često prihvatljiv od strane različitih profesija ( $p a$ i od samih socijalnih radnika) i u velikoj mjeri je u skladu s našom kulturom individualizma (Callero, 2017.). Međutim, identitet je isto toliko društveni, koliko je i psihološki proces, te ne treba zanemariti višestruke i složene društvene čimbenike koji utječu na izgradnju identiteta. U tom slučaju, riskiramo da društvenu nejednakost svedemo na problem osobe. U prilog tome pridonosi i istraživanje AASWSW (American Academy of Social Work and Social Welfare) koje naglašava da društveni čimbenici mnogo snažnije pridonose individualnom stanju ljudi nego bilo koji drugi (npr. bolest, genetika, tehnologija i sl.) (AASWSW, 2016). Odnosno, prikazuje na koji način obitelj i socijalna podrška, stopa obrazovanja, društvene mreže, sigurnost zajednice i sl. kao društveni čimbenici mogu utjecati na stanje pojedinca i njegove snage. Sukladno tomu, gore navedeno istraživanje zaključuje da je razumijevanje načina na koji društveni čimbenici stupaju $\mathrm{u}$ interakcije s drugim silama presudno za budućnost (razvoja) profesije socijalnog rada, kao i za budućnost razvoja i rasta profesionalaca iz ove domene.

Za Freirea srž uloge socijalnog radnika je u njegovu odnosu prema promjeni. Odnosno, socijalni radnik ne bi trebao biti neutralan prema dehumanizaciji i humanizaciji, niti prema stabilnosti situacije koja više ne predstavlja put humanosti (Freire, 1981.). Nasuprot tome, socijalni radnici se moraju suočiti s trenutkom odluke i izabrati stranu koja je usmjerena humanizaciji. Odnosno, socijalni radnici trebaju promišljati o ljudima s kojima rade i zajedno postati svjesni poteškoća u društvu. Ovo dalje implicira tezu da oni trebaju povećati i neprestano širiti svoje znanje, ne samo o metodologiji i tehnici, već i o objektivnim ograničenjima s kojima se susreću.

Osnaživanje je u stvari primarna misija socijalnog rada (vidi i Pinderhughes, 1983.; Rappaport, 1984.). U prilog tomu svjedoči i etički kodeks NASW (National asso- 
ciation of Social Workers) u kojemu se eksplicitno navodi da je jedna od najvažnijih točaka socijalnog rada "unaprjeđenje ljudskog blagostanja i pomoć zadovoljavanju temeljnih ljudskih potreba svih ljudi, s posebnom pozornošću na potrebe i osnaživanje ljudi koji su ranjivi, potlačeni i žive u siromaštvu (NASW, 1996.: 1). Sagledamo li literaturu socijalnog rada, pristupi koji su usredotočeni na snagama privlače posebnu pozornost posljednjih godina. Perspektive snaga primjenjive su u mnogim područjima prakse socijalnog rada, odnosno u radu s: osobama s teškoćama u razvoju (i njihovim obiteljima), LGBT populacijom, beskućnicima, kulturnim i nacionalnim manjinama, izoliranim osobama starije životne dobi, ovisnicima i sl. Ovo su samo neka od polja u kojima koncept osnaživanja zauzima vrlo važno mjesto. Sve više se u ovome kontekstu govori i u obiteljskim terapijama, etničko-senzitivnim programima i različitim rodno specijaliziranim savjetovanjima itd. Naime, o tomu koliko je osnaživanje tema današnjeg socijalnog rada, govori i Dominelli (2012.) koja navodi i probleme poput trgovine ljudima, masovnih migracija, klimatskih promjena itd.

Freire je smatrao kako je obespravljenima i potlačenima potrebno da upoznaju svoje težnje i svoje snage, i u tom kontekstu zagovarao je ideju osnaživanja, odnosno socijalnog djelovanja i podizanja svijesti o značaju ravnopravnog obrazovanja za sve (Christian i Jhala, 2015.). U tom smislu, njegove ideje nedvojbeno mogu pomoći razumijevanju suvremenog socijalnog rada koji se temelji na praksi osnaživanja, ali i na razumijevanju drugih antidiskriminatornih praksi. Naime, socijalni radnici trebali bi osnažiti ljude da se osjećaju dovoljno snažnima da pokrenu i provedu akcije usmjerene k promjeni (Brenton, 1994.). Ili, drugim riječima, socijalni radnici trebali bi poticati moć (tj. kapacitet za promjenu) kod ljudi u cilju postizanja kontrole nad svojim životima (Rappaport, 1984.). U tom smislu, socijalni radnik ne bi trebao sebe promatrati kao eksperta, nego kao edukatora u široj zajednici, a za ovo su potrebne vještine slušanja, uzajamnog povjerenja, kritičkog razmišljanja, ali i uvjerenje da se ljudi mogu promijeniti koje mora postojati i kod edukatora i kod onih koji prolaze kroz proces edukacije (Christian i Jhala, 2015.).

Vrlo značajan autor u kontekstu socijalnog rada i perspektive snaga je i Dennis Saleebey koji eksplicitno prepoznaje Freireov značaj za socijalni rad. Ili, drugim riječima, Freireovo naslijeđe inspiriralo je Saleebeyovu perspektivu snaga koja je vrlo značajna u kontekstu današnjeg socijalnog rada. Naime, Saleebey sugerira kako pojedinci i skupine često imaju ogromne, neiskorištene fizičke, emocionalne, kognitivne i socijalne resurse i kompetencije. Odnosno, oni imaju snage i sposobnosti koje mogu dovesti do promjene. Za razliku od pristupa koji se usredotočuju na deficit i problem, Saleebey smatra da su ljudi motivirani iskoristiti svoj kapacitet za promjenu kada je naglasak na njihovim snagama (Saleebey, 2006.). Naime, također je bitno napraviti razliku između ovog pristupa od pristupa utemeljenih na pozitivnim razmišljanjima. Ovdje je naglasak na angažiranju osobe (odnosno korisnika usluge) u kognitivnim 
razmišljanjima koji će dovesti do preživljavanja, promjene ponašanja i/ili okruženja. Ili, drugim riječima, korisnici bi trebali biti dijelom procesa promjene, od definiranja vlastite situacije, utvrđivanja ciljeva, odabira budućih aktivnosti do same evaluacije rezultata (vidi i Brenton, 2004.).

Slično Saleebeyu, i/ili Freireu, Zastrow i Kirst-Ashman (Zastrow i Kirst-Ashaman, 1997.) sugeriraju kako je snaga u ljudima i da socijalni radnici imaju zadaću dati sve najbolje od sebe, izbjegavajući paternalističke tretmane, uz uvjerenje da svaki korisnik usluge može donijeti odgovarajuću odluku. U tom kontekstu, Rapp i Goscha (2006.) upozoravaju i na neprikladnost zajedničkog imenovanja i generaliziranja korisnika usluga. Na primjer, osoba s bolesti shizofrenije, nerijetko se imenuje kao shizofreničar, te bismo trebali biti osjetljiviji i obzirniji glede distinkcije između "ja sam bolestan" i "ja sam osoba koja ima bolest". Naime, često stručna literatura obiluje podacima o problemima, nemoći, viktimizaciji i sl., te profesionalci prepoznaju nedostatke, neadekvatno funkcioniranje, nesposobnosti dok se, zapažaju Weick i suradnici prednosti korisnika često zapostavljaju i zanemaruju (Weick i sur., 1989.).

Proširenje prakse osnaživanja, pored toga što donosi gore navedene dobrobiti, izloženo je i različitim preprekama i izazovima u današnjem društvu. Koji su izazovi današnjeg socijalnog rada u području osnaživanja? Naime, proširenje prakse osnaživanja zahtijeva posebnu profesionalnu kompetenciju socijalnih radnika. Kako bi ilustrirali ovu točku, navest ćemo neko od istraživanja. Projekt "Osnaživanje obitelji s teškoćama u razvoju" koji je proveden u Rusiji 2011. godine, demonstrira dobar primjer na koji se način socijalni radnici suočavaju s različitim izazovima u ovom području. $U$ istraživanje je bilo uključeno 80 socijalnih radnika iz vladinog i nevladinog sektora koji su osiguravali usluge socijalne zaštite. Jedno od pitanja koje je bilo postavljeno socijalnim radnicima glasilo je "Jeste li upoznati s odgovarajućim metodama socijalnog rada čiji je cilj osnaživanje klijenata kako bi se poboljšala njegova sposobnost za samostalno suočavanje s teškim situacijama?" (Torronen, Borodkina, Samoylova i Heino, 2013.: 32). Samo 10\% ispitanika odgovorilo je potvrdno, odnosno s "da, svjestan sam", dok je čak $75 \%$ socijalnih radnika odgovorilo da su im potrebne dodatne vještine i znanja. S druge strane, $15 \%$ ispitanika dalo je negativan odgovor. Jedna od izvedenih preporuka iz ovog projekta jest povećanje kompetentnosti socijalnih radnika u korištenju metoda osnaživanja koje su prožete kritičkim razumijevanjem, znanjem i vještinama u odgovarajućem kontekstu vrijednosti.

Adams (2003.) također opisuje potencijalnu prepreku u kontekstu osnaživanja korisnika usluga. Neki korisnici usluga jednostavno ne žele surađivati i osnažiti se. Neki od potencijalnih razloga mogu biti da se plaše kako će promjena uvjetovati odbacivanje od bliskih ljudi, neki su uvjereni da im pomoć nije potrebna, dok netko ne želi iz straha od etiketiranja i stigmatizacije. S druge strane, ako pak žele, smatra Rondeau (2000.), na individualnoj razini nije lako "dati moć" onima koji su najviše marginalizi- 
rani iz različitih razloga (npr. beskućnici, ovisnici i sl.). Dok, recimo, Cummings (1980.) smatra kako je u ovoj profesiji zaposleno nerazmjerno mnogo žena, koje same čine skupinu koja je, povijesno gledano, bila potlačena i nemoćna, čak i unutar profesije socijalnog rada, te postavlja pitanje adekvatnog osnaživanja svojih korisnika.

Izazovi osnaživanja kreću se i u smjeru postavljanja pitanja je li moguće da socijalni rad kao obespravljena profesija osnažuje svoje korisnike? (European Social Network, 2012.). S obzirom na to da socijalni radnici često nisu osobito moćna skupina koja može vršiti pritisak na vlasti. Pored toga, mnogi ljudi vide sustav socijalne zaštite samo kao platformu za ublažavanje siromaštva pojedinaca/skupine ili pružanje ciljane pomoći pojedincima ili skupinama. Naime, socijalna zaštita trebala bi biti osmišljena da promiče blagostanje čitavog stanovništva, odnosno potrebno je promatrati je u jednom širem kontekstu, a ne (samo) kao strategiju/mjeru koja pruža olakšice pojedincima (ili skupinama) koji nisu "uspješni” u svojim društvima (Rappaport, 1984.).

Na kraju, Freire se slaže s marksističkim stavom da neke skupine ljudi imaju istaknutije i moćnije uloge u povijesti i da su sukladno tomu u mogućnosti kontrolirati druge (Roberts, 2010.). Međutim, kao što je rečeno, to ne znači da skupine "pod kontrolom" tvore individue bez sposobnosti i određenih snažnih strana. Freire smatra kako ne možemo očekivati pozitivne rezultate (u našem slučaju u praksi socijalnog rada), ako ne poštujemo poseban (tj. individualiziran) pogled na svakog pojedinca i na njegove snage ${ }^{3}$.

\section{REKONCEPTUALIZACIJA ODNOSA SOCIJALNOG RADNIKA I KORISNIKA USLUGA}

U Pedagogiji potlačenih (Freire, 1970.) Freire kritizira pasivan pristup obrazovanju, u smislu da učenici pasivno slušaju i bez primjedbi usvajaju sadržaj koji im je servira edukator. Snažno se protivio tom "bankarskom" modelu obrazovanja, te je predlagao autentično ili liberatorno obrazovanje (putem "postavljanja problema"), koje pretpostavlja da i edukatori i studenti imaju nešto važno pridonijeti obrazovnom sustavu. Drugim riječima, i edukatori i studenti uče jedni od drugih i podučavaju jedni druge, jer svi oni imaju određene vještine, znanja, ali i vrijednosti koje unose u taj pedagoški odnos. U svome djelu, navodi sljedeće tvrdnje koje su kompatibilne tadašnjem brazilskom obrazovnom režimu, ali i mnogo šire:

3 U kasnijim djelima Freire (1998.a) zagovara progresivnu postmodernu poziciju po pitanju opresije, oslobođenja, politike različitosti itd. i inzistira na tome da se indvidua ne može razumjeti i shvatiti samo na temelju kolektivističkih obilježja, poput klase, rase ili roda, ali isto tako, naglašava da ta obilježja ne smijemo ni izostaviti iz analiza, jer utječu na to što individua radi, kako misli i što govori (Giroux i McLaren, 1997.). U biti, to znači da bilo koji pojedinačan aspekt individue ne može objasniti što čovjek jest (Roberts, 2003.). 
a) edukator podučava, a učenici su podučeni; b) edukator zna sve, a učenici ne znaju ništa; c) edukator razmišlja, a učenici su oni za koje edukator razmišlja; d) edukator govori, a učenici slušaju - poslušno; e) edukator disciplinira, a učenici su disciplinirani; f) edukator bira i nameće svoj izbor, a učenici se pokoravaju; g) edukator radi, a učenici imaju privid da rade preko rada edukatora; $h$ ) edukator bira sadržaj programa, a učenici (koji nisu konzultirani) se prilagođavaju; i) edukator zamjenjuje autoritet znanja njegovim ili njenim profesionalnim autoritetom koji je u suprotnosti od slobode učenika; j) edukator je subjekt procesa učenja, a učenici su puki objekti (Freire, 1970.: 71).

U tom smislu, naglasak jes na znanju koje se ne promatra kao neutralno, statično tijelo informacija i vještina koje se (jednosmjerno) prenose od "svemoćnog" edukatora $\mathrm{k}$ učeniku, nego se vidi kao nešto što se aktivno konstruira, ali isto tako i osporava. Definirajući obrazovanje putem postavljanja problema, on odbacuje mogućnost neutralnosti i jasno stavlja do znanja svoje etičke i političke premise (Freire, 1976.). Ono za cilj ima ojačati subjektivnost i djelatni potencijal potčinjenih studenata, te ih vidi kao kokreatore povijesti i kulture u kojoj žive. To je dijaloško i kolaborativno obrazovanje, gdje se čuju studenti, gdje se vodi računa i o njihovim interesima, perspektivama i slično. Na taj se način mogu uočiti dehumanizirajuće prakse, kao i odnosi moći koji su u temeljima društvenog uređenja (Freire, 1998.). Prethodno navedeno implicira tezu da ljudski umovi nisu skladišta gdje se znanje lako može deponirati. Drugim riječima, ljudi odlučuju o svojim vrijednostima i stvarnosti koja ih okružuje.

Sukladno tome, potiču se ispitivanje, kritika i debata i zato je cilj takvoga obrazovanja otkriti ideološka iskrivljenja znanja, kako bi se bolje shvatila stvarnost, te kako bi ljudi bolje shvatili sami sebe i svoje mjesto u svijetu. To se ne može postići samo putem mišljenja, tako da se osviještenje ili kritička svijest mogu steći samo kroz akciju, odnosno kroz praksis. Tu praksu Freire je nazvao dijalogom, kako bi naglasio komunikativnost i stvaranje značenja, čime dijalog postaje središnji element pedagoškog procesa. Međutim, dijalog nije samo puka konverzacija, niti ponašanje tijekom konverzacije, nego suradnja tijekom kritičkog istraživanja o tomu zbog čega potlačeni ljudi nisu u stanju svjesno i namjeravano proizvoditi kulturu i društvo koje je u skladu s temeljnim ljudskim pravima, a to istraživanje kreće od akcija koje dovode u pitanje i nadilaze ta situacijska ograničenja. Ova vrsta dijaloga omogućava podčinjenim ljudima iskazati svoje mišljenje i izmjestiti se iz "kulture tišine", ali ne samo putem jezika, nego i akcija koje za cilj imaju dovesti u pitanje i transformirati institucije i odnose moći u društvu (Freire, 1998.a). U tom smislu, Freire u svojemu djelu navodi da "samo kroz komunikaciju ljudski život može imati značenje" (Freire, 1970.: 77). Kultura tišine, prema Freireu, nastaje upravo iz sustava u kojemu je komunikacija jednosmjerna, tj. koja se kreće od dominantne kulture k potlačenoj. Drugim riječima, to je sustav 
koji se u potpunosti temelji na monologu - jedna skupina govori, a druga skupina sluša, odnosno jedna skupina kreira pravila, a druga ih skupina prati (Freire, 1981.). Suprotno tomu, Freire smatra kako bi dijalog trebao stajati u temelju svake suradnje.

Relevantna u ovom kontekstu je i Freireova ideja da stvarnost koju kreiramo i rekreiramo oblikuje naše obrasce razmišljanja (Freire, 1972.). Naime, Freireovu ideju o dijalogu i obrascima razmišljanja možemo lako dovesti u vezu i s Habermasovom komunikacijskom akcijom koja može također imati značajne implikacije na odnos socijalni radnik-korisnik usluga (Habermas, 1984., 1987.). Njegova komunikacijska akcija označava kooperativnu akciju koju poduzimaju individue na temelju zajedničke odluke i koja je utemeljena na argumentiranju. Strukture ovakvoga govora podrazumijevaju odsutnost sila prisile, zajedničku potragu za razumijevanjem i snagu ili "pobjedu" boljeg argumenta. Samo na ovaj način, smatra Habermas, moguća je pojava intersubjektivne racionalnosti koja čini komunikaciju mogućom. Ovo je otvorena i refleksivna racionalnost u kojoj pojedinci mogu učiti jedni od drugih (kao i od samih sebe), navoditi određene aspekte vlastitog znanja stečenog kulturom, kao i dovoditi u pitanje ove kulturno usađene pretpostavke koje se obično ne preispituju.

Također, slično Freireu, Habermas izlaže kritiku procesa modernizacije kao nefleksibilnog procesa vođenog ekonomskom i administrativnom racionalizacijom. Pisao je o tome kako svakodnevni život građana biva oblikovan formalnim sustavima koji djeluju u interesima države blagostanja, korporativnog kapitalizma i masovne potrošnje, što su procesi koji racionaliziraju i javnu sferu (Habermas, 1991.). Habermasova forma kritičke teorije izgrađena je kako bi analizirala pozitivne potencijale za ljudsku racionalnost preko forme jezika, kao i mogućnosti za kritičku formu razuma koja može voditi u (pre)ispitivanje objektivnih pitanja, kao i društvenih normi, ljudskih vrijednosti i slično. Iz tih razloga, njegova teorija o komunikativnoj akciji (slično Freireovom dijalogu) ima značajne društvene implikacije na socijalni rad.

Kada je o demokratskim temeljima društva riječ, sloboda, demokracija i kritičko mišljenje/sudjelovanje su ključne ideje koje predstavljaju jezgru Freireove kritičke pedagogije. Današnji obrazovni sustavi obično se opisuju terminima poput relacijsko, pluralističko i fragmentirano, a suprotno tome, Freire naglašava univerzalizam, reciprocitet, dijalog, cjelinu ili poredak (Freire, 1998.a). S obzirom na to da odbacuje dihotomiju edukator/student, on ukazuje na određeni reciprocitet između njih, koji promatra kao osnažujući element interakcije. Povijesno gledano, reciprocitet nije nova ideja, ali postaje vrlo značajna u svijetlu brzih društvenih transformacija. U smislu definiranja, reciprocitet je blisko povezan i s konceptima kao što su socijalna podrška, povjerenje, zajednica i građanska participacija, koji predstavljaju temelj cjelokupne profesije socijalnog rada (Morrow, 1999.). Pored toga, ovaj je koncept snažno povezan i s istraživačkom tradicijom socijalnog kapitala (vidi i Bourdieu, 1984.; 
Coleman, 1990.; Putnam et al., 1994.) gdje se proučavaju transformacije u društvu.

Je li moguće ključne Freireove koncepte transferirati u domenu socijalnog rada, odnosno koliko su njegove ideje značajne za rekonceptualizaciju odnosa između socijalnih radnika i korisnika usluga?

Vidjeli smo da je bit dijaloškog odnosa da su svi sudionici u dijalogu jednaki, odnosno da svaki sudionik uči od drugog i da svaki podučava drugog (Freire, 1998.). Naravno, nije prijeporno kako će socijalni radnik imati neke vještine i uvide koje korisnik usluge nema, ali i korisnik ima iskustva i uvide koje socijalni radnik nema. Što znači da se dijalog odvija razmjenom ideja, neslaganjem s tuđim razmišljanjima, dogovorom, raspravom, odnosno bez hijerarhije koja ometa pravo na zauzimanje vlastitog stava i/ili neslaganje. Primijenimo li to na područje socijalnog rada, socijalni radnik nije tu samo kako bi rješavao probleme, socijalni radnik nas uči drugačijem načinu razmišljanja. Kako bi bilo jasnije, možemo uzeti primjer iz prakse, odnosno rad s roditeljima koji zanemaruju dijete radeći neke "loše" roditeljske postupke. Naime, socijalni bi radnici trebali moći shvatiti širu sliku, odnosno shvatiti kako su ti roditelji često zaokupljeni svojim vlastitim potrebama i problemima te da im je, iz različitih razloga, teško jasno se usredotočiti na djetetove potrebe. Sukladno tomu, promatramo li intervenciju socijalnog radnika kroz prizmu Freireovog dijaloga, socijalni bi radnici trebali uključiti roditelje u konstruktivan rad, odnosno zajedno raditi na postizanju ciljeva. Naime, na taj način, roditeljima će biti omogućeno iskazivanje njihova mišljenja, stavova i ideja, odnosno, socijalni radnici će ih podržati i ohrabriti da otvoreno komuniciraju i izraze sebe. Kroz dijalog, odnosno suradnju, socijalni radnici će ih nastojati osnažiti drugačijim načinima razmišljanja. Ili, drugačije rečeno, socijalni radnici će ojačati kapacitete roditelja kako bi oni bili spremniji u budućnosti se nositi s takvim izazovima. Garavan (2013.), slično Freireu, tvrdi da dijaloški proces sam po sebi vraća ljudskost korisniku i socijalnom radniku, omogućavajući im pozabaviti se krajnjom svrhom u socijalnom radu - transformacijom subjekta i društva (White, 2008.).

S druge strane, nije prijeporno da se socijalni rad bori s iskustvom dijaloga, uzajamnosti i reciprociteta od svog ranog razvoja kao profesije (vidi i Addams, 1902.), a kada je profesionaliziran, usvojeni su i objektivni znanstveni pristupi (za rad s korisnicima usluga) koji su (prvotno) pokuša(va)li isključiti uzajamnost i reciprocitet. Kako je profesija evoluirala i stasala, preispitivali su se kvaliteta i važnost prakse koja je utemeljena na odnosima i sukladno tomu došlo se do pristupa koji uvažava i razumije uzajamnost i reciprocitet, te identificira čimbenike i vještine koje pridonose istom. Povjerenje, vjerodostojnost, profesionalna zrelost, samoregulacija i sustavna perspektiva samo su neke od kvaliteta socijalnih radnika koji pridonose reciprocitetu u socijalnom radu (Alexander, 2005.). Kao što smo ranije naveli, kori- 
snici usluga trebali bi imati aktivnu ulogu u rješavanju svojih problema, a ne samo pasivno primati naredbe ili instrukcije od socijalnih radnika. Također, Freire spominje kako često dehumaniziramo ljude, odnosno promatramo ih kao predmete ili stvari, što bi u kontekstu prakse socijalnog rada značilo da u njezino središte ne bi trebalo stavljati problem, njegov ishod ili posljedice, nego osobu, njezinu percepciju, njezine vrijednosti i sl. (vidi i Christian i Jhala, 2015.).

Sukladno tomu, u domeni socijalnog rada, reciprocitet ima dubok značaj za pojedince (socijalne radnike i korisnike usluga) i jedan je od najvažnijih čimbenika u ostvarivanju (individualnog i društvenog) blagostanja. Čitanje Freireovih ideja o reciprocitetu između učitelja i učenika, (uz male modifikacije), možemo, kako smo vidjeli, prepoznati i u dijadi socijalnog radnika i korisnika.

\section{PROMIŠLJANJA U PRAVCU RASTA I RAZVOJA SOCIJALNIH RADNIKA KAO PROFESIONALACA}

Prema mišljenju Freirea, akcija je ključna za razvoj nas kao ljudskih bića, ali istovremeno je vrlo bitan element i u procesu transformacije, što implicira tezu da nas akcija, kao vid refleksije, motivira na pokret - omogućava nam testirati ideje, izraziti kreativnost, ali i postati pokretačima povijesnih promjena. U ovome kontekstu bitno je spomenuti da se Freire nije zalagao za reforme koje bi temeljne političke strukture ostavile netaknutim, nego za radikalne, revolucionarne promjene. Smatrao je kako je dehumanizacija povijesna realnost, ali da se ne mora prihvatiti kao neizbježna (Freire, 1972.). Ona se manifestira kroz represivne strukture, politike, odnose, prakse i ideje, te su u tom kontekstu kritička preispitivanja i pokušaji rekonstrukcije društva, kako bi ono postalo pravednije i demokratsko, omogućile potlačenim ljudima da shvate što legitimizira dehumanizaciju u društvu. Uz pomoć osviještenja, oni mogu dovesti u pitanje društvene, ekonomske i političke strukture koje održavaju moć dominantnih skupina, ali i interne psihološke strukture koje održavaju njihovu potlačenu i obespravljenu egzistenciju (Freire, 1998.a).

Sukladno tomu, ključna načela u Freirevoj pedagogiji potlačenih su razvoj određenih vrlina ili posvećenost dijalogu, refleksija, kritička svijest i humanizacija prakse. Zato se on protivi nekritičkom pristupu i sagledavanju situacije, odnosno ustrajava na tomu kako nema univerzalnih propisa, već se sve mora analizirati situacijskom logikom ili, drugim riječima, sve je ovisno o kontekstu (Roberts, 2010.), te su i odabrani postupci i metode također kontekstualno ovisni. Zato refleksivna praksa ima vrlo važno mjesto u njegovu sustavu, kao što ga ima i u obrazovanju i praksi socijalnog rada. Kretanje k refleksivnoj praksi socijalnog rada očituje se kroz kontinuirano (kritičko) 
ispitivanje načela na kojima se temelji, a slično tomu, cilj Freireove radikalne/kritičke pedagogije jest da dovede do transformacijskih akcija (vidi i Freire, 1972.). Naime, tvrdi Freire: "Znanje nastaje samo izumom i ponovnim izumom, kroz nemirna, nestrpljiva, neprekidna i puna nade ispitivanja ljudskih bića koja se obavljaju u svijetu, sa svijetom i jedni s drugima" (Freire, 2011.:51).

Odnosno, ta kritička ispitivanja i pokušaji rekonstruiranja društva kako bi postalo pravednije i demokratsko, omogućavaju podčinjenima da bolje upoznaju "zdrav razum" svakodnevice koji legitimizira dehumanizaciju. Preko osvještavanja, odnosno kritičke svijesti, oni mogu dovesti u pitanje ne samo društvene, ekonomske i političke strukture koje održavaju moć dominantnih skupina, nego i interne psihološke strukture koje održavaju njihov dobrovoljan ostanak u stanju potlačenosti (Freire, 1998.a). Iz tog razloga, sposobnost razmišljanja o praksi na otvoren i sustavan način smatra se ključnim za odgovornu profesionalnu praksu socijalnog rada. Refleksivna praksa je jedan od temeljnih koncepata u socijalnom radu, a njegovo podrijetlo leži u radu Donalda Schona (1983.) koje ima značajne implikacije i na kritički socijalni rad. U svojemu radu Schon upozorava na krizu u različitim profesijama i ukazuje na jaz između formalne teorije i stvarne prakse. U tom smislu, refleksija se odnosi na razmišljanje o svom iskustvu i povezivanju svoje prakse s prethodnim znanjem i iskustvima. Schon objašnjava kako je to u stvari znanje o akciji, odnosno improvizacija na licu mjesta. Vrlo je ilustrativan primjer s vožnjom bicikla, gdje on objašnjava da, krenemo li padati na lijevu stranu, točno znamo što ćemo uraditi na licu mjesta kako ne bismo pali, međutim često ćemo dati pogrešan odgovor izvan te situacije. Sukladno prethodno rečenom, profesija socijalnog rada zahtijeva i neprekidnu improvizaciju. Kako je neupitno da socijalni radnici pomažu ljudima u prevladavanju različitih socijalnih problema, nije prijeporno da se oni susreću s različitim stresnim i/ili nasilnim situacijama, te sama profesija, pored teorijskog i praktičnog znanja, zahtijeva, kao što smo rekli, i visoku prilagodljivost, improvizaciju i (samo)refleksiju. Na temelju Freireovog promišljanja o refleksiji, bitno je skrenuti pozornost i na pristupe koji predlažu kreativnost, improvizaciju, maštu, igranje uloga i kazalište kao tehnike koje predstavljaju korisne alate u razvoju prakse socijalnog rada (Uggerhoj, 2008.). Naime, pomoću ovih tehnika socijalni radnici mogu se postaviti u položaj korisnika i doživjeti njegovu situaciju, što svakako pridonosi kvalitetnijoj praksi socijalnog radnika. S druge strane, kao što i sam Freire tvrdi, ovakve perspektive omogućavaju dijeljenje moći i recipročan odnos socijalnog radnika i korisnika o kojem smo ranije govorili. U tom kontekstu, Travithick (2012.) promatra socijalne radnike i načine na koje (ne) uspijevaju ostati staloženi u trenucima kada su korisnici usluga u nevolji, ili ih uvlače u njihovu tugu, sram, strah itd. Iskustva dosadašnjih istraživanja (npr. Schon, 1983.; Remond, 2006.) govore nam i da se mnoge prakse obavljaju intuitivno i temelje na osobnom i profesionalnom znanju i iskustvu stečenom tijekom života. 
Sukladno gore navedenom, socijalni radnici se ohrabruju pohađati različite kvalificirane programe kako bi se uključili u različite refleksivne procese. To podrazumijeva preispitivanje njihovih pretpostavki, predrasuda i/ili stereotipa u pravcu razmišljanja što drugi osjećaju i/ili misle. Naime, naše jas treba postojati u smislu osobnosti i identiteta, međutim treba također biti otvoreno za promjene. Refleksivnu praksu neki autori nazivaju i "unutarnjim supervizorom" (vidi npr. Ingram i Smith, 2018.), dok Brookfield (2017.) tvrdi da je refleksivno razmišljanje osnažujući i pozitivan proces za praktičare socijalnog rada, koji u velikoj mjeri pridonosi njihovoj samosvjesnosti i većoj učinkovitosti u radu s korisnicima usluga. Odnosno, može se sagledati i kao način približavanja razumijevanju vlastitoga života, svojih akcija, ali i razmišljanju korisnika usluga. Refleksivna praksa u socijalnom radu često je povezana i sa samosvjesnošću i emocionalnom inteligencijom (vidi i Gilgun, 2008.). Samosvjesnost se u ovom kontekstu odnosi na sposobnost praktičara da se usredotoči na razmišljanje o vlastitoj praksi, te da bude svjestan odnosa između njegova položaja (npr. u organizaciji, u radu s korisnicima i sl.) i procesa razmišljanja o učincima te iste prakse. S druge strane, emocionalna inteligencija najčešće je definirana kao sposobnost prepoznavanja, ali $i$ razumijevanja emocije u sebi i kod drugih. Slično tomu, Freire smatra da u (pedagoškom) procesu samospoznaje učenici ili studenti također otkrivaju sebe kao povijesne subjekte, odnosno kao ljude koji su u stanju transformirati opresiju (Freire, 1998.a).

Freire, dakle, smatra da treba poštovati razne i različite glasove, marginalizirane skupine, razne religije, jezike itd., što implicira kako nije važna perspektiva iz koje netko dolazi ili u kojoj se nalazi. Ova je teza važna i za temelje socijalnog rada, a može se povezati i s kulturno kompetentnom praksom o kojoj će nešto više riječi biti u idućem odjeljku. Uloga socijalnog radnika u ovom bi kontekstu trebala biti facilitatorska, jer stvara kontekst i okvir za različite promjene. Odnosno, pokušava vidjeti ljude iz njihove unutrašnjosti - kako govore, kako konstruiraju svoje misli i svoje vrijednosti. Kao katalizatori promjena, socijalni radnici trebali bi biti osposobljeni vidjeti percepcije različitih korisnika, odnosno povezati činjenice i probleme i razumjeti ih. Kako bi lakše razumjeli ovu tvrdnju, možemo ilustrirati primjer iz prakse socijalnog rada. Ako je naš korisnik migrant kojemu je potrebna pomoć da se uključi u društvo, sa stanovišta refleksije, mogli bismo se zapitati sljedeće: Kakav odnos imam prema korisniku? Imam li predrasude i kako one mogu utjecati na to što sam učinio/la ili protumačio/la? Koji jezik/obrasce/riječi koristim? Kako sam konstruirao/ la sebe i svoju moć u odnosu na korisnika usluge? Koja su moja trenutna uvjerenja? Drugi primjer mogao bi se odnositi na problem siromaštva, gdje bi socijalni radnici trebali razumjeti problem siromaštva mnogo šire nego neuspjeh samog korisnika, odnosno kao manifestaciju političke, ekonomske i društvene nepravde, što znači kako treba razumjeti i veze između siromaštva, ekonomske politike, reakcije na njih, 
nasilje izazvano siromaštvom i glađu i sl. i u odnosu na to preispitati svoja uvjerenja i praktične radnje. To sve znači da je jedan od glavnih ciljeva, ali i izazova, razviti holističku perspektivu promatranja (Christian i Jhala, 2015.).

Koje su neke od prednosti refleksije u praksi socijalnog rada? Hess (1995.) tvrdi kako ona može pridonijeti "ljudskom procvatu", odnosno boljoj primjeni znanja, kao i sposobnosti za korištenje prethodnih iskustava na novim slučajevima. Slično tome, Fook i Napier (2000.) smatraju da refleksija poboljšava praksu i stvara nove mogućnosti, te povećava sposobnost reagiranja u promjenama i neizvjesnim situacijama. Pored toga, različita istraživanja (npr. Hess, 1995). prikazuju da refleksivna praksa povećava i kolegijalnost (npr. poboljšava odnose između socijalnih radnika, između socijalnih radnika i supervizora, između profesionalaca i različitih organizacija socijalne zaštite itd.), povećava motivaciju i želju za iznalaženjem novih pristupa, mjera i/ili strategija i sl.

S druge strane, vrlo je značajno granice refleksije u potpunosti prepoznati, odnosno važno je da socijalni radnici ne budu pogrešno shvaćeni ili patologizirani očekivanjima kako bi trebali u svakom trenutku promišljati o svakom svojem koraku. Iz tog razloga, vrlo je važno da obrazovanje socijalnih radnika potiče kritičko i kreativno razmišljanje, refleksiju i analizu u svojim kurikulumima, odnosno u nastavnim planovima i programima. Na taj način, budući stručnjaci bit će upoznati s takvom vrstom djelovanja, te će kasnije u svojoj praksi moći iskoristiti naučene alate za usmjeravanje svojih profesionalnih akcija.

\section{Doprinos kulturnoj kompetentnosti socijalnih radnika}

Freire (1994.) je smatrao da potlačeni ljudi često ostaju bez glasa i izbora, odnosno da su apatični i asimilirani u dominantnoj kulturi - oni postaju ovisni, osjećaju se inferiorno i otuđeni su od svoje kulture. tj. postaju nemoćni. Zato ističe da se ta opresija javlja kada društvene, ekonomske, političke i ideološke strukture sprječavaju neke ljude ili skupine ljudi da ostvare svoje osnovne potrebe i da budu slobodni, kako bi oblikovali povijest i kulturu u kojoj žive (vidi i Freire, 1998.a, 1998.b). U tom smislu, opresija predstavlja oblik dehumanizacije, a istovremeno lišava čovjeka prava na slobodu.

Ljudsku slobodu Freire je vidio kao kulturni artefakt koji je smatrao izvorom transformacije. Odnosno, transformacija pojedinca (ili društva) nije pružanje kulturnih činjenica koje će uvećati naše znanje, nego su to različite forme našeg kulturnog iskustva (Freire, 1998.b). Na taj način ljudi kritički razmišljaju o svojim kulturnim identitetima i kulturnim iskustvima u svezi s drugima, te u tom smislu Freire (1974.) smatra da je vrlo važan razvoj kritičke svijesti koja uključuje refleksivnu svijest o razlikama 
u moći, a koja može dovesti do kolaborativnog rješavanja problema i rehumanizirati ljudske odnose. Slično je i u socijalnom radu, gdje kulturna kompetentnost, najkraće rečeno, podrazumijeva razvoj akademske i profesionalne ekspertize i vještine u radu s kulturno različitim klijentima (vidi i Škorić, Kišjuhas i Škorić, 2015.). Odnosno, kao što i sam Freire tvrdi, kulturna kompetentnost prvenstveno se razvija preko istraživanja vlastitog kulturnog identiteta, kulturne pozadine i kontakata s korisnicima različitih etničkih pripadnosti (Freire, 1998.b).

Zato se može reći da je neophodna kritička samorefleksija, koja ne podrazumijeva puku usredotočenost na sebe, nego predstavlja jedan korak unatrag u shvaćanju vlastitih pretpostavki, predrasuda i vrijednosti i promjenu samog sebe, kao i promjenu odnosa s drugim ljudima u smjeru socijalne pravde i pravičnosti (Freire i Macedo, 1995.; Kumagai i Lypson, 2009.). U prethodnom podnaslovu naglasak je bio na analizi Freireovog koncepta refleksivne prakse i njezina značaja za socijalni rad, a očigledno je koliko je ona značajna za jednu od temeljnih koncepata u socijalnom radu - kulturnu kompetentnost. Neki autori (npr. Ferguson, Lavalette i Whitmore, 2005.; Reich i Reich, 2006.), slično Freireu, smatraju da je kulturna kompetentnost u stvari dugogodišnja posvećenost samokritici i samorefleksiji, te da predstavlja proces, a ne krajnje i nepromjenjivo stanje. Također, Rothman (2008.) sugerira da vještine kulturne kompetentnosti treba modificirati prema specifičnim potrebama $\mathrm{i}$ pogledima na svijet korisnika.

U tom smislu, nužno je da socijalni radnik tijekom obrazovanja stekne određeni korpus znanja o različitim kulturama, ljudskim karakteristikama, interkulturnim razlikama u običajima, vjerovanjima, vrijednosnom sustavu i sl., jer će često biti u poziciji ponuditi tretman i procjenu koja bi trebala biti kulturno relevantna za različite korisnike usluga (Škorić, Kišjuhas i Škorić, 2015.). Pored kulturnog znanja, nije zanemariva ni kulturna empatija, zato što u odnosu s korisnikom nisu dovoljne samo činjenične informacije o njegovoj kulturi kako bi se ostvario smislen i adekvatan kontakt - nije dovoljno samo poštovanje drugih kultura, nego i aktivno angažiranje. U protivnom, može se javiti situacija u kojoj će se socijalni radnik osjetiti zbunjenim ili nesigurnim, te se vratiti na mehaničke principe rada, kada postoji opasnost od pružanja nekonzistentne i nekompetentne usluge, odnosno usluge slabije kvalitete. Odnosno, kulturna kompetencija treba biti dugoročno nastojanje i cilj kojemu će težiti profesionalci, a ne tretirati je kao jednokratnu inicijativu. U kontekstu današnjih problema i izazova, lako možemo izvesti primjer kada su nam korisnici romske nacionalnosti, a kojima se susrećemo svakodnevno. Neke od tema o kojima bismo trebali razmišljati su sljedeće: na koji način procjenjujemo korisnike, pojedinačno ili u odnosu na njihovu obitelj, zajednicu, kulturu i sl.? Koliko smo upoznati s romskom kulturom i njihovim vrijednosnim sustavom? Smatramo li ponašanje naših korisnika disfunkcionalnim samo zbog toga što se ne podudaraju s dominantnim obrascima kulture? 
Preispitivanje vlastitih vrijednosti je vrlo težak zadatak zbog snažnog emocionalnog utjecaja stavova, vjerovanja i osjećaja koji su povezani s kulturnim razlikama, međutim to je jedini put koji će dovesti do kulturno kompetentnog socijalnog rad(nik) a i do redukcije rasizma, seksizma, diskriminacije i sl. National Association of Social Workers iz SAD-a stalno apelira na socijalne radnike da se posvete različitim programima i obukama koje unaprjeđuju kulturnu kompetentnost te da razvijaju kritičku svijest kako bi pružali (kulturno) kompetentnije usluge svojim korisnicima (NASW, 2007.). Pregledom literature, dolazimo do zaključka da su suradnja, komunikacija, kolegijalnost nad konkurentskim individualizmom, samorefleksija, dijalog, jedinstvenost individua, bezuvjetno prihvaćanje, kritičko razmišljanje, socijalna pravda, poštovanje različitih kultura, kulturna empatija, samosvijest o vlastitoj kulturi i sl. samo neke od točaka presjeka Freireovog nasljeđa i kulturno kompetentnog socijalnog rada.

\section{ZAKLJUČNA RAZMATRANJA I IZAZOVI PROFESIJE SOCIJALNOG RADA}

Kao što se može vidjeti, Freireov rad odlikuju brojne tenzije, koje su mahom posljedica njegove sumnje u stvarne mogućnosti obrazovanja u klasno utemeljenom društvu. Promatran kao cjelina, njegov rad nema za cilj pokazati samo mogućnosti i potencijale obrazovanja, nego je cilj pokazati njegov značaj i značenje kao prakse koja je osvješćujuća, humanizirajuća, oslobađajuća i dijaloška. Ideja dijaloga možda je i najspecifičniji Freireov doprinos kritičkoj pedagogiji, a samim tim može se translirati i u područje socijalnog rada. Dijalog je važan jer, kao što je objašnjeno, mijenja odnose svih sudionika, i tlačitelja i potlačenih, kao i odnose među njima, te je zato nužan u svakoj autentičnoj revoluciji.

Ipak, Freireove ideje otkrivaju novu perspektivu promatranja obrazovanja u kontekstu društvene promjene. Naglašavajući kritičku svijest, reciprocitet, refleksivnu praksu, dijalog, liberatorno, tj. oslobađajuće obrazovanje, itd., kritizira postojeće modele obrazovanja kao nekompatibilne realnim potrebama današnjice. Njegova filozofija obrazovanja povezuje refleksiju s akcijom u procesu različitih društvenih, ekonomskih i političkih transformacija, te akcentira poticanje (potlačenih) ljudi i odvajanje od, odnosno napuštanje, individualističkog razmišljanja. Ovakvo holističko i strukturno promatranje problema može pridonijeti povećanju interne konzistentnosti i proaktivnosti unutar profesije socijalnog rada, koja bi trebalo više naglašavati dijalog, reciprocitet, holističko promatranje korisnika, kritičko razmišljanje, inovativne programe, spremnije promovirati socijalnu pravdu itd.

Naime, ključna Freireova poruka (socijalnim radnicima) odnosi se na to da je potrebno duboko razmisliti o tome koji su najučinkovitiji načini rada s ljudima. Ljudski 
životi su složeni, a njihovi izbori i akcije nisu vođeni samo interesom, nego, kako smo ranije naveli, višestrukim i složenim motivacijama. $U$ prilog tomu govori i činjenica da se ljudi ne ponašaju kao samodovoljni pojedinci, nego su gotovo uvijek uključeni i ugrađeni u društvene i kulturne mreže obitelji, prijatelja i zajednice. Freireova ideja o dijalogu možda najbolje oslikava sveobuhvatno razumijevanje problema, potpuno sudjelovanje korisnika i učinkovitu mobilizaciju korisnikovih vlastitih resursa i resursa profesionalne mreže podrške.

Koji su potencijalni izazovi u kontekstu današnjeg socijalnog rada? Današnji socijalni rad funkcionira s unaprijed podešenim kategorijama usluga, te se stoga očekuje da se korisnici uklope u ove kategorije. Freireov dijalog je, u stvari, umjesto odgovora "mi pružamo ovu uslugu", usredotočen na pitanje "što je vama potrebno?". Sukladno tomu, od socijalnih radnika se ne traže vještine propisivanja, prepisivanja i usmjeravanja, nego vještine stvaranja odnosa i kompetencije za vođenje dijaloga (Garavan, 2013.). Odnosno, važna Freireova poruka za socijalne radnike jest da ne budu profesionalni "popravljači", nego da postanu facilitatori humanizacije i promjena usmjerenih prema humanizaciji. Sve ovo su važni izazovi za suvremeni socijalni rad kao znanost i kao profesiju, te je čitanje Paula Freirea kroz ovu prizmu pokušaj da se njegove ideje uključe, i prije svega, uvaže u već postojeće postulate socijalnog rada.

lako nikada nije napisao, niti objavio koherentno djelo iz područja socijalnog rada, njegovo nasljeđe i teorijske koncepte koje je razvio moguće je (uz određeni stupanj adaptacije), kao što smo vidjeli, primijeniti i u profesiji socijalnog rada koristeći različite analogije. Koncepti poput osnaživanja, reciprociteta, refleksivne prakse, kulturno-kompetentne prakse, samo su neki od onih koji nedvojbeno mogu pridonijeti kritičkom promatranju današnjeg socijalnog rada, rekonceptualizaciji odnosa socijalni radnik-korisnik usluga, kao i razvoju ključnih kompetencija socijalnih radnika kao profesionalaca.

\section{LITERATURA}

1. Addams, J. (1961). Twenty years at hull-house. New York: Signet, MacMillan.

2. Addams, J. (1902). Democracy and social ethics. Urbana and Chicago: University of Illinois Press.

3. Alexander, C. (2005). Social workers' experiences of being cared for by their clients. Vancouver: RRIT. Preuzeto s: https://open.library.ubc.ca/clRcle/ collections/ubctheses/831/items/1.0092015 (29.3.2020.)

4. American Academy of Social Work \& Social Welfare (2016). Create social responses to a changing environment. Preuzeto s: http://aaswsw.org/ grand-challenges-initiative/12-challenges/create-social-responses-to-a-c- 
hanging-environment (29.3.2020.)

5. Best, B. Bonefeld, W. \& O'Kane, C. (eds.) (2018). The SAGE Handbook of Frankfurt school critical theory, Three Volumes. London: SAGE.

6. Bilinović, A. \& Škorić, J. (2015). Obrazovanje kao čimbenik socijalnog razvoja. U: Sokolovska, V. (ur.), Regioni i regionalizacija: Komparativna analiza IV. Novi Sad: Filozofski fakultet, 43-62.

7. Brenton, M. (1994). On the meaning of empowerment and empowerment-oriented social work practice. Social Work with Groups, 17 (4), 23-37.

8. Bourdieu, P. (1988). Homo academicus. Stanford: Stanford University Press.

9. Bourdieu, P. (1993). The field of cultural production: Essays on art and literature. New York: Columbia University Press.

10. Brookfield, S. (2017). Becoming a critically reflective teacher, $2^{\text {nd }}$ Edition. San Francisco: Jossey-Bass.

11. Callero, P. L. (2017). The myth of individualism. New York: Rowman \& Littlefield Publishers.

12. Cho, S. (2013). Critical pedagogy and social change: Critical analysis on the language of possibility. London and New York: Routledge.

13. Christian, A. \& Jhala, N. (2015). Social work needs Paulo Freire. International Journal of Humanities and Social Science Invention, 4 (6), 36-39.

14. Coleman, J. (1990). Foundations of Social Theory. Cambridge: Harvard University Press.

15. Collins, D. E. (1977). Paulo Freire: His life, works and thought. New York: Paulist Press.

16. Cornwall, A. \& Brock K. (2005). Beyond buzzwords: "Poverty reduction", "participation" and "empowerment" in development policy. Geneva: UN-RISD

17. Cummings, J. (1980). Sexisam in social work: Some thoughts on strategy for structural change. Catalyst, 11 (4), 7-34.

18. Dearing, T. C. (2017). Social services, social justice, and social innovations: Lessons for addressing income inequality, Religions 2 (1), 1-14.

19. Dewey, J. (1902). The child and the curriculum. Chicago: The University of Chicago Press.

20. Dominelli, L. (2002). Feminist social work theory and practice. Basingstoke: Palgrave Macmillan.

21. European Social Network (2012). The challenges currently facing social services: A view from the public sector. Preuzeto s: https://www.esn-eu. org/sites/default/files/publications/2012_The_challenges_currently_facing_social_services_EN.pdf. (29.3.2020.)

22. Ferguson, I. (2008), Reclaiming social work: Challenging neo-liberalism and promoting social Justice. London: Sage.

23. Ferguson, I., Lavalette, M. \& Whitmore, E. (2005). Globalisation, global justice and social Work. London and New York: Routledge. 
24. Fook, J. (2002). Social work: Critical theory and practice. London: Sage Publications.

25. Franklin, A. (1986). The neglect of Experiment. Cambridge: Cambridge University Press.

26. Freire, P. (1970). Pedagogy of the oppressed, $30^{\text {th }}$ Anniversary Edition. New York and London: Continuum.

27. Freire, P. (1972). Cultural action for freedom. Harmondsworth: Penguin.

28. Freire, P. (1973). Education as the practice of liberty. New York: McGraw Hill.

29. Freire, P. (1976). Education: The practice of freedom. London: Writers and Readers.

30. Freire, P. (1981). Education for critical consiciousness. London: Bloomsbury.

31. Freire, P. (1994). Pedagogy of hope. New York: Continuum.

32. Freire, P. (1998a). Pedagogy of freedom: Ethics, democracy, and civic courage. Lanham: Rowman \& Littlefield.

33. Freire, P. (1998b). Teachers as cultural workers: Letters to those who dare teach. Boulder: Westview Press.

34. Freire, P. (2004). Pedagogy of indignation. London and New York: Routledge.

35. Freire, P. \& Macedo, D. (1995). A dialogue: Culture, language, and race. Harvard Educational Review, 65 (3), 377-402.

36. Fromm, E. (1964). The heart of man: Its genius for good and evil. New York: Harper \& Row.

37. Gadotti, M. (1994). Reading Paulo Freire: His life and work. New York: SUNY Press.

38. Gadotti, M. \& Torres C. A. (2009). Paulo Freire: Education for development. Development and Changes, 40 (6), 1255-1267.

39. Garavan, M. (2013). Dialogical practice in social work - towards a renewed humanistic method. Journal of Social Intervention: Theory and Practice 22 (1), 4-20.

40. Gilgun, J. F. (2008). Lived experience, reflexivity and research on perpetrators of interpersonal violence. Qualitative Social Work, 7 (2), 181-197.

41. Giroux, H. A. \& McLaren, P. (1997). Paulo Freire, postmodernism, and the utopian imagination: A Blochian reading. In: Daniel, J. O. \& Moylan, T. (eds.), Not yet: reconsidering Ernst Bloch. London and New York: Verso, 138-162.

42. Goroff, N. (1981). Humanism and social work paradoxes, problems, and promises. The Journal of Sociology \& Social Welfare 8 (1), 1-10.

43. Gordon, P. E., Hammer, E. \& Honneth, A. (eds.) (2019). The Routledge companion to the Frankfurt School. New York and London: Routledge.

44. Gottesman, I. (2016). The critical turn in education: From Marxist critique to poststructuralist feminism to critical theories of race. New York: Routledge.

45. Habermas, J. (1984). The theory of communicative action, Volume 1: Reason and the rationalization of society. Boston: Beacon Press. 
46. Habermas, J. (1987). The theory of communicative action, Volume 2: Lifeworld and system: A critique of functionalist reason. Boston: Beacon Press.

47. Habermas, J. (1991). The structural transformation of the public sphere: an inquiry into a category of burgeois society. Cambridge: The MIT Press.

48. Hayes, W. (2006). The progressive education movement: Is it still a factor in today's schools? Lanham: Rowman \& Littlefield Education.

49. Hegar, R. L. (2012). Paulo Freire: Neglected mentor for social work. Journal of Progressive Human Services, 23 (2), 159-177.

50. Horkheimer, M. (1982). Critical theory. New York: Seabury Press.

51. Ingram, R. \& Smith, M. (2018). Relationship-based practice: Emergent themes in social work literature. Dundee: Iriss.

52. Kahn, R. (2010). Critical pedagogy, ecoliteracy, \& planetary crisis: The ecopedagogy movement. New York: Peter Lang.

53. Kanpol, B. (1999). Critical pedagogy: An introduction, $2^{\text {nd }}$ Edition.Westport and London: Bergin \& Garvey.

54. Kumagai, A. K. \& Lypson M. L. (2009). Beyond cultural competence: Critical consciousness, social justice, and multicultural education. Academic Medicine, 84 (6), 782-787.

55. Labonte, R. (1990). Empowerment: Notes on professional and community dimensions. Canadian Review of Social Policy, 26, 64-75.

56. McClelland, D. C. (1975). Power: The inner experience. New York: Irvington Publishers.

57. McLaren, P. (1996). Paulo Freire and the academy: A challenge from the U.S. Left. Cultural Critique, 33, 151-184.

58. Naiper, L. \& Fook, J. (2000). Reflective practice in social work. In: Napier, L. \& Fook, J. (eds.), Breakthoughs in practice: Theorising critical moments in social work. Whiting \& Birch, pp. 1-15.

59. NASW (2007). Indicators for the achievement of the NASW standards for cultural competence in social work practice. Washington: NASW.

60. Parsons, R. J. (1991). Empowerment: Purpose and practice principle in social work. Social Work with Groups, 14 (2), 7-21.

61. Payne, M. (2005). Modern social work theory, $3^{\text {rd }}$ Edition. Chicago: Lyceum Books.

62. Payne, M. (2006). What is professional social work. UK: Policy Press.

63. Piaget, J. (1972). Psychology and epistemology: Towards a theory of knowledge. Harmondsworth: Penguin.

64. Pinderhughes, E. B. (1983). Empowerment for our clients and for ourseIves. Social Casework, 64 (6), 331-338.

65. Putnam, R.D., Leonardi, R. \& Nanetti, R.Y. (1994). Making democracy work: Civic traditions in modern Italy. New Jersey: Princeton University Press.

66. Rapp. C. A. \& Goscha, R. J. (2006). The strenghts model: Case management 
with people with psychiatric disabilities. New York: Oxford University Press.

67. Rappaport, J. (1984). Studies in empowerment: Introduction to the issue. Prevention in Human Services, 3 (2-3), 1-7.

68. Reich, S. M. \& Reich, J. A. (2006). Cultural competence in interdisciplinary collaborations: A method for respecting diversity in research partnerships. American Journal of Community Psychology, 38 (1-2), 51-62.

69. Roberts, P. (2003). Pedagogy, neoliberalism and postmodernity: Reflections on Freire's later work. Educational Philosophy and Theory 35 (4), 451-465.

70. Roberts, P. (2010). Paulo Freire in the 21st Century: Education, dialogue and transformation. Boulder: Paradigm Publishers.

71. Rondeau, G. (2000). Empowerment and social practice, or the issue of power in social work. Canadian Social Work, 2 (1), 216-222.

72. Rose, S. M. (2000). Reflections on empowerment-based practice. Social Work, 45 (5), 403-412.

73. Rothman, J. C. (2008). Cultural competence in process and practice: Building Bridges. Boston: Allyn \& Bacon.

74. Salebeey, D. (2006). The strenghts perspective in social work practice. Boston: Pearson/Allyn \& Bacon.

75. Schon, D. A. (1983). The reflective practitioner: How professionals think in action. New York: Basic Books.

76. Solomon, B. B. (1976). Black empowerment: Social work in oppressed communities. New York: Columbia University Press.

77. Spring, J. (1989). The sorting machine revisited: National educational policy since 1945, Updated Edition. New York and London: Longman.

78. Škorić, M., Kišjuhas, A. \& Škorić, J. (2015). Značaj kulturne kompetentnosti za socijalni rad. Godišnjak Filozofskog fakulteta, 40, 189-207.

79. Torronen, M., Borodkina, O., Samoylova, V. \& Heino, E. (2013). Empowering social work: Research \& practice. Helsinki: Palmenia Centre for Continuing Education.

80. Vygotsky, L. (1978). Mind in Society: The development of higher psychological processes. Cambridge and London: Harvard University Press.

81. Webb, S. A. (2006). Social work in a risk society: Social and political pespectives. UK: Mcmillan International Higher Education.

82. Weick, A., Rapp, C., Sullivan, W.P. \& Kirsthardt, W. (1989). A strenghts perspective for social work practice. Social Work, 34 (6), 350-354.

83. Wilson, E. O. (1984). Biophilia: The human bond with other species. Cambridge: Harvard University Press.

84. Zastrow, Ch. \& Kirst-Ashman, K.K. (1997). Understanding human behavior and the social environment. Michigen: Nelson-Hall. 
Jovana Škorić

University of Novi sad

Faculty of Philosophy

Department of social work

Marko Škorić

University of Novi sad

Faculty of Philosophy

Department of sociology

\section{RECONCEPTUALISATION OF FREIRE'S HERITAGE IN THE CONTEXT OF SOCIAL WORK}

\section{ABSTRACT}

The aim of this paper is to attempt to reconceptualise, sum up and analyse the main heritage of the Brazilian philosopher and educator Paul Freire and present its significance for social work. Since few authors analysed this issue, the paper will primarily aim to provide a more coherent framework of Freire's ides in the context of social work that have already been examined. Namely, the paper will present in what manner his ides, such as critical pedagogy, reflexive practice, critical thinking, dialogue, empowerment, reciprocity and many others, influence social work practice. The aforementioned Freire's ideas which are relevant for social work are grouped into three areas: (1) critical social work, empowerment and re-evaluation of the position of social work in society, (2) ideas that could be used for reconceptualisation of the relationship between a social worker and a client, and (3) ideas directed towards reflection on growth and development of social workers as professionals. Following the analysis of the aforementioned concepts and areas, the final part of the paper leaves room for assessing the relevance of Freire's theoretical frameworks with the aim of developing key competences of the social work profession which are focused on dialogue, progressive social changes and overall social development, as well as on the challenges in the context of contemporary social work.

Key words: Paulo Freire, critical pedagogy, critical social work, empowerment, reflexive practice, social workers. 